\title{
Study of Drying Kinetics of Cauliflower (Brassica oleracea) using Tray Dryer
}

\author{
Pinkoo Singh ${ }^{1} *$, B. R. Singh ${ }^{1}$, Sweta Singh $^{2}$, Neelash Chauhan ${ }^{1}$, \\ Ratnesh Kumar $^{1}$, Rahul Kumar ${ }^{1}$ and Yogendra Singh ${ }^{1}$ \\ ${ }^{1}$ Department of Agricultural Engineering, Sardar Vallabhbhai Patel University of Agriculture \\ and Technology, Meerut, India \\ ${ }^{2}$ College of Agriculture Kumher, Bharatpur, S.K.N.University, Jobner, Jaipur, India
}

*Corresponding author

\section{A B S T R A C T}

Keywords

cauliflower, tray drying, drying rate, moisture content

Article Info

Accepted:

24August 2019

Available Online:

10 September 2019
Cauliflower is one of several vegetables in the species Brassica oleracea in the genus Brassica, which is in the family Brassicaceae. The present investigation were carried out to determine the drying kinetics (Moisture content $\mathrm{wb} \% \& \mathrm{db} \%$, dehydration ratio, average drying rate, etc.) of cauliflower under cabinet tray drying $\left(60{ }^{0} \mathrm{C}\right)$. Moisture content $(w b \%)$ of samples ranges from 94.53 to 09.90 and moisture content (db \%) ranges from 1729.49 to 10.99 at $60{ }^{\circ} \mathrm{C}$ of tray drying temperature. Drying rate and dehydration ratio were ranged from 3.38 to 0.07 and 1.38 to 1.07 respectively.

\section{Introduction}

Cauliflower is relatively difficult to grow compared to cabbage. Failure to head properly and poor curd quality are common problems. For successful production of cauliflower, a fertile, moist soil relatively high in organic matter and nitrogen is needed. Cauliflower buttoning is the premature formation of curd, and since the curd forms very early in the plant's life, the leaves are not large enough to nourish the curd to a marketable size. Conditions that reduce the vigor of the plant and retard vegetative growth, such as cold temperatures at transplanting, appear to encourage buttoning.

Cauliflower is one of several vegetables in the species Brassica oleracea in the genus Brassica, which is in the family Brassicaceae. It is an annual plant that reproduces by seed. Typically, only the head is eaten - the edible white flesh sometimes called "curd" (Fritz et al., 2017). Fruits and vegetables are important source of vitamins and their drying demands special attention for their nutritional aspects of the end product (Mudgal and Pandey 2009; Shalini et al., 2009). The drying operation in 
convective heating involves moisture transfer from the wet material to heated air, which may be illustrated as a transport of moisture from the material core to its surface, followed by evaporation from the surface of the material, and dissipation of water vapour into the bulk of the drying air. (Maskan et al., 2002; Togrul and Pehlivan, 2002) Drying causes irreversible structural damage to the cellular structure of foods, whereby rehydration of the dehydrated product affected.

Pretreatment, subsequent drying and rehydration may induce changes in the structure and composition of plant tissues (Lewicki, 1998) which affect the organoleptic properties upon rehydration.

A number of studies for drying of fruits and vegetables have been reported by various authors (Doymaz 2006; Akpinar, 2006; Eren and Kaymak-Ertekin, 2007).

Drying is a common technique for preservation of food and other products; including fruits and vegetables. The major advantage of drying food products is the reduction of moisture content to a safe level that allows extending the shelf life of dried products.

The removal of water from foods provides microbiological stability and reduces deteriorative chemical reactions. Also, the process allows a substantial reduction in terms of mass, volume, packaging requirement, storage and transportation costs with more convenience (Okos et al., 1992).

\section{Materials and Methods}

Fresh fully matured white and compact cauliflower heads were selected for the experiment. The leaves were removed and heads were thoroughly washed, trimmed to remove hard main stem and cut into pieces of
3-4 $\mathrm{cm}$ length and $2-3 \mathrm{~cm}$ width.

\section{Drying Methods}

(AOAC, 2000)

Cabinet tray drying $\left(60{ }^{\circ} \mathrm{C}\right)$

\section{Pretreatments}

The cauliflowers were cut (pieces and quarter) then blanching and steeping pretreatments were given.

\section{Blanching}

Hot water blanching method was used. The samples were blanched in boiling water at 100 ${ }^{\circ} \mathrm{C}$ for $3 \mathrm{~min}$. The gas stove was used to boil the water and the temperature was maintained. Each time $500 \mathrm{gm}$ of sample was taken and dipped into boiling water for 3 min.

\section{Treatment with $0.25 \% \mathrm{KMS}$ + citric acid solution (blanched+ steeped)}

The samples were blanched and then drained for $30 \mathrm{~min}$, cooled and then soaked in $0.25 \%$ citric acid solution along with $0.25 \% \mathrm{KMS}$ for $30 \mathrm{~min}$ at room temperature. After $30 \mathrm{~min}$ the samples were taken out of solution and drained again before drying.

\section{Statistical Analysis}

The entire experiment was replicated three times. All the data were analyzed by MS excel and results were expressed as mean \pm standard deviation (SD).

\section{Results and Discussion}

The experimental data of drying kinetics of control $\left(\mathrm{T}_{1}\right)$ cauliflower samples in tray dryer at $60{ }^{\circ} \mathrm{C}$ is presented in Table 1 . According to data, moisture content (wb \%) of samples ranges from 94.53 to 09.90 and moisture 
content (db \%) ranges from 1729.49 to 10.99 at $60{ }^{\circ} \mathrm{C}$ of tray drying temperature. Drying rate and dehydration ratio were ranged from 3.38 to 0.07 and 1.38 to 1.07 respectively. It took about 720 minutes to dry samples completely at $60{ }^{\circ} \mathrm{C}$. The experimental data of drying kinetics of blanched cauliflower samples $\left(\mathrm{T}_{2}\right)$ in tray dryer at $60{ }^{\circ} \mathrm{C}$ is presented in Table 2.

According to data, moisture content ( $w b \%$ ) of samples ranges from 94.53 to 15.47 and moisture content $(\mathrm{db} \%)$ ranges from 1729.49 to 18.31 at $60{ }^{\circ} \mathrm{C}$ of tray drying temperature. Drying rate and dehydration ratio were ranged from 3.15 to 0.23 and 1.37 to 1.20 respectively. It took about 720 minutes to dry the samples completely at $60{ }^{\circ} \mathrm{C}$. The experimental data of drying kinetics of blanched + steeped cauliflower samples $\left(T_{3}\right)$ in tray dryer at $60{ }^{\circ} \mathrm{C}$ is presented in Table 3 .

According to data, moisture content ( $w \mathrm{~b} \%$ ) of samples ranges from 94.53 to 1.38 and moisture content $(\mathrm{db} \%)$ ranges from 1729.49 to 1.40 at $60{ }^{\circ} \mathrm{C}$ of tray drying temperature. Drying rate and dehydration ratio were ranged from 2.96 to 0.02 and 1.59 to 1.02 respectively. It took about 720 minutes to dry the samples completely.

There is a decrease in drying rate and dehydration ratio. The moisture content decreased with increase in time but the curves of drying rate were found to be non linear during drying operation.

Table.1 Drying kinetics of control cauliflower samples in tray dryer at $60{ }^{\circ} \mathrm{C}$

\begin{tabular}{|l|l|l|l|l|l|l|}
\hline $\begin{array}{l}\text { Time } \\
\text { (Min.) }\end{array}$ & $\begin{array}{l}\text { Sample } \\
\text { weight }(\mathbf{g})\end{array}$ & $\begin{array}{l}\text { M.C. } \\
\mathbf{( \% ,}, \mathbf{w b})\end{array}$ & $\begin{array}{l}\text { M.C. } \\
\mathbf{( \% ,}, \mathbf{d b})\end{array}$ & $\begin{array}{l}\text { Water } \\
\text { removed }(\mathbf{g})\end{array}$ & $\begin{array}{l}\text { Drying } \\
\text { rate }\end{array}$ & $\begin{array}{l}\text { Dehydration } \\
\text { ratio }\end{array}$ \\
\hline $\mathbf{0}$ & 500.000 & 94.53 & 1729.49 & 0.00 & 0.00 & 0.00 \\
\hline $\mathbf{6 0}$ & 407.667 & 93.30 & 1391.65 & 92.33 & 3.38 & 1.23 \\
\hline $\mathbf{1 2 0}$ & 321.000 & 91.49 & 1074.53 & 86.67 & 3.17 & 1.27 \\
\hline $\mathbf{1 8 0}$ & 246.667 & 88.92 & 802.55 & 74.33 & 2.72 & 1.30 \\
\hline $\mathbf{2 4 0}$ & 186.667 & 85.36 & 583.01 & 60.00 & 2.20 & 1.32 \\
\hline $\mathbf{3 0 0}$ & 135.333 & 79.81 & 395.18 & 51.33 & 1.88 & 1.38 \\
\hline $\mathbf{3 6 0}$ & 98.500 & 72.25 & 260.41 & 36.83 & 1.35 & 1.37 \\
\hline $\mathbf{4 2 0}$ & 71.333 & 61.69 & 161.01 & 27.17 & 0.99 & 1.38 \\
\hline $\mathbf{4 8 0}$ & 51.667 & 47.10 & 89.05 & 19.67 & 0.72 & 1.38 \\
\hline $\mathbf{5 4 0}$ & 41.000 & 33.34 & 50.02 & 10.67 & 0.39 & 1.26 \\
\hline $\mathbf{6 0 0}$ & 35.667 & 23.37 & 30.50 & 5.33 & 0.20 & 1.15 \\
\hline $\mathbf{6 6 0}$ & 32.333 & 15.47 & 18.31 & 3.33 & 0.12 & 1.10 \\
\hline $\mathbf{7 2 0}$ & 30.333 & 9.90 & 10.99 & 2.00 & 0.07 & 1.07 \\
\hline
\end{tabular}


Table.2 Drying kinetics of blanched cauliflower samples in tray dryer at $60{ }^{\circ} \mathrm{C}$

\begin{tabular}{|l|l|l|l|l|l|l|}
\hline $\begin{array}{l}\text { Time } \\
(\mathbf{M i n} .)\end{array}$ & $\begin{array}{l}\text { Sample } \\
\text { weight }(\mathbf{g})\end{array}$ & $\begin{array}{l}\text { M.C. } \\
(\mathbf{\%}, \mathbf{w b})\end{array}$ & $\begin{array}{l}\text { M.C. } \\
\mathbf{( \% ,} \mathbf{d b})\end{array}$ & $\begin{array}{l}\text { Water } \\
\text { removed }(\mathbf{g})\end{array}$ & $\begin{array}{l}\text { Drying } \\
\text { rate }\end{array}$ & $\begin{array}{l}\text { Dehydration } \\
\text { ratio }\end{array}$ \\
\hline $\mathbf{0}$ & 500.000 & 94.53 & 1729.49 & 0.00 & 0.00 & 0.00 \\
\hline $\mathbf{6 0}$ & 414.013 & 93.40 & 1414.87 & 85.99 & 3.15 & 1.21 \\
\hline $\mathbf{1 2 0}$ & 334.140 & 91.82 & 1122.61 & 79.87 & 2.92 & 1.24 \\
\hline $\mathbf{1 8 0}$ & 259.670 & 89.48 & 850.13 & 74.47 & 2.72 & 1.29 \\
\hline $\mathbf{2 4 0}$ & 196.380 & 86.08 & 618.55 & 63.29 & 2.32 & 1.32 \\
\hline $\mathbf{3 0 0}$ & 146.980 & 81.41 & 437.80 & 49.40 & 1.81 & 1.34 \\
\hline $\mathbf{3 6 0}$ & 107.540 & 74.59 & 293.49 & 39.44 & 1.44 & 1.37 \\
\hline $\mathbf{4 2 0}$ & 85.260 & 67.95 & 211.96 & 22.28 & 0.82 & 1.26 \\
\hline $\mathbf{4 8 0}$ & 70.390 & 61.17 & 157.56 & 14.87 & 0.54 & 1.21 \\
\hline $\mathbf{5 4 0}$ & 58.360 & 53.17 & 113.54 & 12.03 & 0.44 & 1.21 \\
\hline $\mathbf{6 0 0}$ & 47.250 & 42.16 & 72.89 & 11.11 & 0.41 & 1.24 \\
\hline $\mathbf{6 6 0}$ & 38.667 & 29.32 & 41.48 & 8.58 & 0.31 & 1.22 \\
\hline $\mathbf{7 2 0}$ & 32.333 & 15.47 & 18.31 & 6.33 & 0.23 & 1.20 \\
\hline
\end{tabular}

Table.3 Drying kinetics of blanched + steeped samples in tray dryer at $60{ }^{\circ} \mathrm{C}$

\begin{tabular}{|l|l|l|l|l|l|l|}
\hline $\begin{array}{l}\text { Time } \\
\text { (Min.) }\end{array}$ & $\begin{array}{l}\text { Sample } \\
\text { weight }(\mathbf{g})\end{array}$ & $\begin{array}{l}\text { M.C. } \\
(\mathbf{\%}, \mathbf{w b})\end{array}$ & $\begin{array}{l}\text { M.C. } \\
\mathbf{( \% ,} \mathbf{d b})\end{array}$ & $\begin{array}{l}\text { Water } \\
\text { removed }(\mathbf{g})\end{array}$ & $\begin{array}{l}\text { Drying } \\
\text { rate }\end{array}$ & $\begin{array}{l}\text { Dehydration } \\
\text { ratio }\end{array}$ \\
\hline $\mathbf{0}$ & 500.000 & 94.53 & 1729.49 & 0.00 & 0.00 & 0.00 \\
\hline $\mathbf{6 0}$ & 419.000 & 93.48 & 1433.11 & 81.00 & 2.96 & 1.19 \\
\hline $\mathbf{1 2 0}$ & 341.670 & 92.00 & 1150.16 & 77.33 & 2.83 & 1.23 \\
\hline $\mathbf{1 8 0}$ & 269.330 & 89.85 & 885.47 & 72.34 & 2.65 & 1.27 \\
\hline $\mathbf{2 4 0}$ & 202.330 & 86.49 & 640.32 & 67.00 & 2.45 & 1.33 \\
\hline $\mathbf{3 0 0}$ & 148.330 & 81.57 & 442.74 & 54.00 & 1.98 & 1.36 \\
\hline $\mathbf{3 6 0}$ & 103.000 & 73.47 & 276.88 & 45.33 & 1.66 & 1.44 \\
\hline $\mathbf{4 2 0}$ & 67.670 & 59.61 & 147.60 & 35.33 & 1.29 & 1.52 \\
\hline $\mathbf{4 8 0}$ & 42.670 & 35.95 & 56.13 & 25.00 & 0.91 & 1.59 \\
\hline $\mathbf{5 4 0}$ & 32.333 & 15.47 & 18.31 & 10.34 & 0.38 & 1.32 \\
\hline $\mathbf{6 0 0}$ & 29.201 & 6.41 & 6.85 & 3.13 & 0.11 & 1.11 \\
\hline $\mathbf{6 6 0}$ & 28.308 & 3.45 & 3.58 & 0.89 & 0.03 & 1.03 \\
\hline $\mathbf{7 2 0}$ & 27.712 & 1.38 & 1.40 & 0.60 & 0.02 & 1.02 \\
\hline
\end{tabular}




\section{References}

Akpinar EK (2006). Mathematical modeling of thin layer drying process under open sun of some aromatic plants. J Food Eng. 77:864-870.

AOAC (2000). Official Methods of Analysis. Association of Official Analytical Chemists, Washington DC.

Doymaz I (2006). Thin layer drying behaviour of mint leaves. J Food Eng. 74:370375.

Eren I, Kaymak-Ertekin F (2007). Optimization of osmotic dehydration of potato using response surface methodology. J Food Eng. 79:344352.

Fritz V. A.; Carl J. R.; Michelle A. G.; William D. H.; Roger L. B.; Cindy T.; Jerry A. W. and Terry T. N. (2017). "Growing broccoli, cabbage and cauliflower in Minnesota". University of Minnesota Extension, Garden - Growing Vegetables.
Lewicki P (1998). Effect of pre-drying treatment, drying and rehydration on plant tissue properties: A review. Int J Food Prop 1(1):1-22.

Maskan A, Kaya S, Maskan M (2002). Hot air and sun drying of grape leather (pestil). J Food Eng. 54:81-88.

Mudgal VD and Pandey VK (2009). Thin layer drying kinetics of bitter gourd. J Food Sci. Technol. 46(3):236-239.

Okos, R. M.; Narsimhan, G.; Singh, R. K. and Weitnauer, A. C. (1992). Food Dehydration. In: Heldman, D.R.; Lund, D. B. (Edt): Handbook of Food Engineering. New York: Marcel Dekker. pp 437-562.

Shalini R, Gupta DK, Singh A (2009). Drying kinetics of apple pomace cake. JFST 46(5):477-479.

Togrul IT, Pehlivan D (2002). Mathematical modelling of solar drying of apricots in thin layers. J Food Eng 55:209-216.

\section{How to cite this article:}

Pinkoo Singh, B. R. Singh, Sweta Singh, Neelash Chauhan, Ratnesh Kumar, Rahul Kumar and Yogendra Singh 2019. Study of Drying Kinetics of Cauliflower (Brassica oleracea) using Tray Dryer. Int.J.Curr.Microbiol.App.Sci. 8(09): 2487- 2491. doi: https://doi.org/10.20546/ijcmas.2019.809.288 